\title{
PENGARUH PEMBELAJARAN BERBASIS PORTOFOLIO DAN KEMAMPUAN AWAL TERHADAP HASIL BELAJAR MEDIA PEMBELAJARAN MAHASISWA PIAUD
}

\author{
Rohani \\ Universitas Islam Negeri Sumatera Utara Medan \\ E-mail: rohanistr@gmail.com \\ Tri Indah kesumawati \\ Universitas Islam Negeri Sumatera Utara Medan \\ E-mail: triindahkesumawati@gmail.com
}

Article received: 5 Februari 2019 Review process: 15 Februari 2019

Article published: 30 March 2019

\begin{abstract}
This paper organizes about the effect of portofolio-based learning and the basic ability toward the result of learning media on students of Islamic Education Early Childhood study program, Faculty of Science and Teacher Training, State Islamic University of North Sumatera. The type of this research is quantitative research which is uses experiment form. The subject in this research is 70 third semester PIAUD students. The instrument that is used in this research is writing. The current data analysis is: analysis of two-way variance. The results of the study have showed that: (1) Students' learning outcomes using portofolio-based learning is better than student learning outcomes using conventional learning. (2) the basic ability influences the improving of student learning outcomes in mastering learning media. (3) Students' learning outcomes that has high ability in basic learning with portofolio based learning are different to the fact and significant to the other group.
\end{abstract}

Keywords: Result of learning, Basic ability, Portofolio-based learning.

\begin{abstract}
Abstrak
Tulisan ini menyajikan tentang pengaruh pembelajaran berbasis portofolio dan kemampuan awal terhadap hasil belajar media pembelajaran mahasiswa prodi Pendidikan Islam Anak Usia Dini Fakultas Ilmu Tarbiyah Dan Keguruan UIN Sumatera Utara. Jenis penelitian ini merupakan penelitian kuantitatif dalam bentuk eksperimen. Subjek dalam penelitian ini adalah 70 orang mahasiswa PIAUD semester III. Instrumen yang digunakan dalam penelitian ini adalah lembar tes. Analisis data yang digunakan pada penelitian ini yaitu: analisis varians dua jalan. Hasil penelitian menunjukkan bahwa: (1) Hasil belajar mahasiswa menggunakan pembelajaran berbasis portofolio lebih baik dibandingkan dengan hasil belajar mahasiswa dengan menggunakan pembelajaran konvensional. (2) kemampuan awal mempengaruhi
\end{abstract}


peningkatan hasil belajar mahasiswa dalam penguasaan media pembelajaran. (3) hasil belajar mahasiswa yangmemiliki kemampuan awal belajar tinggi dengan pembelajaran berbasis portofolio berbeda dengan nyata dan signifikan dengan kelompok perlakuan yang lain.

Kata kunci: hasil belajar, kemampuan awal, pembelajaran berbasis portofolio

\section{PENDAHULUAN}

Pendidikan mempunyai peranan yang sangat penting untuk meningkatkan kualitas sumber daya manusia, sebab pendidikan memiliki peluang dan kekuatan untuk dapat berbuat banyak dalam menjalankan dan menjadikan sumber daya manusia sebagai modal (asset) dasar dalam pembangunan nasional. Maka untuk membangun diperlukan keahlian yang didapat dari dunia pendidikan. Oleh karena pendidikan membuat manusia lebih kreatif dan mandiri dalam mengembangkan kemampuannya untuk merencanakan kehidupan baik untuk diri sendiri maupun untuk bangsa dan negaranya.

Proses pembelajaran yang berkualitas membutuhkan dosen sebagai pengelola dan mengembangkan pembelajaran yang inovatif, yakni pembelajaran yang memiliki gagasan, ide untuk memunculkan strategi, metode atau teknik sebagai cara yang tepat diformulasikan untuk mencapai proses pembelajaran yang efektif. Sebagai seorang perancang dalam pembelajaran, dosen sangat berperan dalam menentukan berhasil tidaknya pencapaian tujuan pembelajaran. Agar tujuan pembelajaran dapat tercapai, dosen dituntut untuk memiliki keterampilan mengajar dan dapat mengorganisasikan bahan pelajaran sedemikian rupa sehingga pembelajaran menjadi menarik.

Pembelajaran berbasis portofolio (portofolio based learning) mengupayakan berbagai keterampilan kepada mahasiswa, terutama yang berkaitan dengan kepekaan dalam menemukan dan menentukan permasalahan yang mendesak untuk segera dipecahkan, merumuskan format permasalahan, menentukan berbagai sumber yang diperkirakan dapat membantu memecahkan permasalahan, melatih melakukan pengumpulan data atau informasi terhadap berbagai sumber yang berhubungan dengan kebijakan publik, merumuskan format laporan hasil pengumpulan data, dan menyajikan portofolio yang berisi upaya pemecahan masalah-masalah dalam pembelajaran.

Untuk mempelajari sesuatu diperlukan sejumlah pengetahuan sebagai dasar permulaan yang lazim disebut bahan apersepsi atau "entry behavior" yaitu kelakuan berupa pengetahuan, 
sikap, dan keterampilan, sebelum memasuki babak baru dalam pelajaran. Kemampuan awal mahasiswa dapat mempengaruhi proses belajar, jika tingkat kemampuannya rendah tetapi masih dilanjutkan ke materi ajar berikutnya tentu dapat menurunkan hasil belajar. Mahasiswa yang sudah pernah menerima suatu materi ajar cenderung bosan atau bahkan kurang merespon, sebaliknya mahasiswa yang belum pernah menerima pelajaran akan lebih respon terhadap materi ajar baru tersebut.

Kemampuan awal mahasiswa dalam suatu kelas sering sangat heterogen, artinya dalam suatu kelas ada yang mudah menguasai materi yang akan diajarkan, ada yang sedikit menguasai, dan ada yang belum menguasai sama sekali. Oleh karena itu, bila seorang dosen tidak mengetahui keberagaman mahasiswa yang diajarnya akan dapat mengakibatkan kelompok mahasiswa yang belum tahu, akan ketinggalan, serta tidak dapat mengikuti pembelajaran yang diberikan dosen, dan bagi kelompok mahasiswa yang sudah tahu akan timbul kebosanan karena materi yang diajarkan sudah diketahuinya.

Sejalan dengan kenyataan yang ada dilapangan bahwa tidak semua mahasiswa memiliki kemampuan awal sesuai dengan materi yang diberikan. Banyak mahasiswa yang memulai pengetahuan awalnya tentang pembelajaran yang akan diberikan pada saat materi tersebut akan disajikan didalam kelas. Oleh sebab itu hasil belajar mahasiswa yang memiliki kemampuan awal terhadap materi yang akan diberikan berbeda dengan mahasiswa yang belum memiliki kemampuan awal terhadap materi yang akan diberikan. Model pembelajaran berbasis portofolio yang diterapkan oleh kelompok dosen yang memperhatikan perkembangan hasil belajar siswa mengupayakan agar hasil belajar siswa dapat menjadi lebih baik.

Penelitian ini didukung oleh penelitian terdahulu yaitu: Ida Ariani (2000) dalam penelitiannya mengemukakan bahwa pembelajaran dengan penggunaan Assesmen portofolio dapat mencapai ketuntasan belajar. Dengan menerapkan Metode Pembelajaran Berbasis Portofolio mahasiswa akan lebih memahami konsep dalam pembelajaran, karena mahasiswa belajar dari pengalaman yang dibawa ke dalam kelas dan akhirnya pengalaman tersebut didiskusikan hingga mendapat sebuah kesimpulan. Didukung pula dengan penelitian terdahulu oleh Sofyan Salam (2000) menemukan bahwa dengan pembelajaran model portofolio dalam penilaian memiliki keunggulan yang mendalam dan secara komprehensif 
dalam pembelajaran. Hasil penelitian tersebut mendukung penelitian ini karena melalui penggunaan model pembelajaran berbasis portofolio dapat mencapai hasil belajar yang baik. Pembelajaran berbasis portofolio merupakan pembelajaran yang diadaptasi dari model "We the People. Project Citizen" yang dikembangkan oleh Center Civic Education (CCE) yang berkedudukan di Calabar, Amerika Sefikat Sampai saat ini telah diadaptasi oleh sekitar 50 negara termasuk Indonesia. Pembelajaran ini bersifat generic-pedagogik, dan materinya dapat disesuaikan dengan kondisi masing-masing negara. Pemilihan pembelajaran berbasis portopolio merupakan langkah yang tepat sebab dapat menghidupkan suasana pembelajaran media pendidikan. Proses yang berpusat pada mahasiswa dimana ide-ide, gagasan, pendapat, sikap dan perbuatan mahasiswa lahir dari hasil pengalaman mahasiswa itu sendiri, yaitu pengalaman mahasiswa yang menyangkut kepentingan bersama merupakan salah satu latar belakang pembelajaran berbasis portofolio (Denny, 2003).

Dari uraian diatas, maka penggunaan model pembelajaran berbasis portofolio dan kemampuan awal sangatlah penting untuk mencapai hasil belajar yang optimal. Oleh karena itu, peneliti tertarik untuk melakukan penelitian dengan judul "Pengaruh Model Pembelajaran Berbasis Portofolio dan Kemampuan Awal Terhadap Hasil Belajar Mahasiswa”.

Berdasarkan uraian di atas, maka dirumuskan beberapa masalah yaitu: (1) apakah mahasiswa Prodi PIAUD semester III yang diajar dengan model pembelajaran berbasis portofolio akan memperoleh hasil belajar media pendidikan yang berbeda dengan mahasiswa yang diajar dengan model pembelajaran konvensional ? (2) Apakah mahasiswa Prodi PIAUD semester III yang memiliki kemampuan awal tinggi menunjukkan hasil belajar yang berbeda, dengan mahasiswa berkemampuan awal rendah? (3) Apakah ada interaksi antara model pembelajaran berbasis portofolio dan kemampuan awal mahasiswa Prodi PIAUD semester III dalam mempengaruhi hasil belajar media pendidikan mahasiswa Prodi PIAUD semester III ?

\section{METODOLOGI}

Penelitian ini dilakukan di ruang kuliah Fakultas Ilmu Tarbiyah dan Keguruan UIN Sumut. Subjek dalam penelitian ini terdiri dari 2 kelas dengan jumlah mahasiswa sebanyak 70 orang. Teknik analisis data yang digunakan untuk pengujian hipotesis adalah Analisis Varians (ANAVA) dua jalan (Two-way-Anova) dengan taraf signifikan a $=0,05$, yang kemudian dilanjutkan dengan uji Tuckey untuk membuktikan ada tidaknya interaksi. Sebelum teknik 
analisis ini digunakan maka terlebih dahulu dilakukan uji persyaratan analisis, dilakukan dengan uji normalitas melalui undian yakni, dari beberapa kelas yang ada diperoleh 2 kelas eksperimen. Dari 2 kelas yang telah terpilih sebagai sampel penelitian, selanjutnya melalui pengundian maka diperoleh jumlah sampel sebanyak 30 orang terpilih sebagai kelas yang akan diajar dengan model pembelajaran konvensional, dan 30 orang terpilih sebagai kelas yang akan diajar dengan menggunakan metode pembelajaran portofolio.

Penelitian ini dilakukan dalam bentuk quasi eksperiment. Penelitian ini melibatkan dua kelompok sampel masing-masing ditetapkan sebagai kelompok eksperimen dan kelompok kontrol. Kelompok eksperimen diberlakukan model pembelajaran berbasis portofolio dan kelompok kontrol diberlakukan model pembelajaran konvensional pada mata kuliah media pembelajaran. Akhir dari eksperimen ini diharapkan mendapat informasi tentang perbedaan hasil belajar pada mata kuliah media pembelajaran mahasiswa melalui pembelajaran berbasis portofolio yang dibandingkan dengan konvensional dengan mengelompokkan sampel penelitian menjadi dua kelompok yaitu mahasiswa yang memiliki kemampuan awal tinggi dan mahasiswa yang memiliki kemampuan awal rendah.

Desain penelitian ini digunakan desain faktorial $2 \times 2$, melalui desain ini akan dibandingkan pengaruh antara model pembelajaran berbasis portofolio dan konvensional terhadap hasil belajar mata kuliah media pembelajaran ditinjau dari kemampuan awal. Uji normalitas menggunakan uji Lilliefors dan uji homogenitas menggunakan uji Barlett, dengan taraf signifikan $5 \%$. Setelah melakukan pengujian persyarat analisis, selanjutnya dilakukan pengujian ANAVA dua jalur.

\section{HASIL DAN PEMBAHASAN}

Pengaruh Model Pembelajaran Konvensional Dengan Portofolio Terhadap Hasil

\section{Belajar Mahasiswa Pada Media Pembelajaran}

Pembelajaran berbasis portofolio (portofolio based learning) mengupayakan berbagai keterampilan kepada mahasiswa, terutama yang berkaitan dengan kepekaan dalam menemukan dan menentukan permasalahan yang mendesak untuk segera dipecahkan, merumuskan format permasalahan, menentukan berbagai sumber yang diperkirakan dapat membantu memecahkan permasalahan, melatih melakukan pengumpulan data atau informasi terhadap berbagai sumber yang berhubungan dengan kebijakan publik, merumuskan format 
laporan hasil pengumpulan data, dan menyajikan portofolio yang berisi upaya pemecahan masalah-masalah kemasyarakatan.

Denny (2003) menyatakan bahwa pemilihan model pembelajaran berbasis portofolio merupakan langkah yang tepat sebab dapat menghidupkan suasana pembelajaran. Proses yang berpusat pada mahasiswa dimana ide-ide, gagasan, pendapat, sikap dan perbuatan mahasiswa lahir dari hasil pengalaman mahasiswa itu sendiri, yaitu pengalaman mahasiswa yang menyangkut kepentingan bersama merupakan salah satu latar belakang pembelajaran berbasis portofolio.

Sedangkan pembelajaran konvensional menempatkan guru sebagai subjek pembelajaran dan sumber utama dalam pembelajaran, peran dan tanggung jawab mahasiswa dalam pembelajaran hanya sebagai objek sehingga mahasiswa tidak aktif dalam pembelajaran. Sudjana (2002) mengatakan konvensional bercirikan antara lain; pembelajaran berorientasi pada materi dan berpusat pada guru, komunikasi yang terjadi cenderung satu arah, kegiatan lebih menekankan mahasiswa mendengar dan mencatat seperlunya, suasana bertanya tidak muncul dari mahasiswa, menyamaratakan kemampuan mahasiswa, dan berorientasi pada target pencapaian kurikulum. Pendapat yang lain dikemukakan oleh Nawawi (2004) bahwa pembelajaran konvensional merupakan pendekatan pembelajaran yang menggunakan guru sebagai sumber tunggal dalam belajar, dengan demikian guru memegang kendali utama dalam menetapkan metode pembelajaran, dan menilai hasil belajar.

Kegiatan yang kontradiksi ini antara pembelajaran berbasis portofolio dan konvensional dalam proses pembelajaran yang menempatkan posisi guru dan mahasiswa sangat berbeda sehingga menghasilkan hasil belajar yang berbeda. Pembelajaran berbasis porofolio dengan menempatkan mahasiswa sebagai subjek pembelajaran dan menempatkan guru sebagai fasilitataor yang menciptasan suasana beajar ebih kondusif dan menyenangkan membuat pembelajaran ini dapat meningkatkan hasil belajar mahasiswa menjadi lebih baik daripada peerapan pembelajaran konvensional.

Berdasarkan data yang diperoleh, menunjukkan bahwa hasil belajar rata-rata bagi kelompok mahasiswa yang diajar dengan portofolio mencapai 22,67 lebih baik dari rata-rata hasil belajar mahasiswa yang diajar dengan konvensional yang hanya mencapai 18,7. Dari hasil perbandingan rata-rata yang diperoleh memberikan simpulan bahwa hasil belajar 
mahasiswa yang diajar dengan pembelajaran portofolio lebih baik dari hasil belajar mahasiswa yang diberi pembelajaran dengan menggunakan konvensional. Hal ini sesuai dengan dugaan sebelumnya yang mengunggulkan pembelajaran portofolio pada pembelajaran Media Pembelajaran.

Keunggulan dari pembelajaran portofolio yang diuraikan pada kerangka berpikir terbukti secara empiris dilapangan, sehingga hasil ini menguatkan bahwa dengan pembelajaran portofolio hasil belajar mahasiswa akan lebih baik. Keunggulan utama dari pembelajaran portofolio yang ditemukan dilapangan adalah bahwa pada setiap tahapan mahasiswa dalam kelompok selalu berpacu untuk mencari informasi yang berhubungan langsung dengan masyarakat artinya mahasiswa belajar langsung secara empirik untuk memecahkan masalah yang ditugaskan oleh guru. Kondisi ini membuat mahasiswa lebih banyak menggali informasi tentang materi pelajaran dengan cara-cara tersendiri, menyajikan portofolio dengan memulai presentasi awal, kemudian masing-masing kelompok akan menyajikan informasi penting tentang tugasnya, lalu diadakan forum tanya jawab dan dewan juri melakukan tanya jawab dengan para mahasiswa (masing-masing kelompok).

Pengaruh Kemampuan awal Tinggi Dan Kemampuan Awal Rendah Terhadap Hasil Belajar Mahasiswa Pada Media Pembelajaran

Seperti diketahui bahwa pengetahuan awal atau prior knowledge mahasiswa sangat penting dalam menguasai materi selanjutnya. Mahasiswa yang memiliki pengetahuan awal yang baik diarapkan akan dapat mengikuti proses pembelajaran lebih baik dan akan mudah menguasai pelajaran yang diberikan terutama dengan pembelajaran yang dirancang lebih baik seperti model pembelajaran berbasis portofolio.

Hasil temuan penelitian membuktikan bahwa mahasiswa yang memiliki kemampuan awal tinggi hasil belajar mereka lebih baik dibandingkan dengan mahasiswa yang memiliki kemampuan awal rendah pada media pembelajaran. Hal ini dapat dipahami bahwa mahasiswa yang memiliki pengetahuan awal tinggi, akan lebih kreatif dan mudah mentrasfer pengetahuannya serta akan termotivasi untuk memecahkan masalah yang dihadapi, sebaliknya mahasiswa yang memiliki kemampuan awal belajar rendah kurang bergairah dalam belajar, kurang berani dalam mengajukan pertanyaan dan kurang berani memberikan komentar terhadap materi yang dipelajari, serta cenderung kurang aktif dalam proses pembelajaran. 
Bloom (1982) mengemukakan bahwa proses belajar di sekolah, prestasi belajar yang diperoleh oleh mahasiswa sebelumya memiliki pengaruh yang kuat terhadap prestasi belajar berikutnya, lebih lanjut ia mengatakan hasil dari suatu kegiatan belajar mencerminkan ciri-ciri awal pebelajar yang akan digunakan untuk kegiatan berikutnya.

Selanjutnya Reigeluth (2001) megidentifikasikan 7 jenis kemampuan awal yang dapat dipakai untuk memudahkan perolehan, pengorganisasian, dan pengungkapan kembali pengetahuan baru. Ketujuh jenis kemampuan ini adalah adalah: (1) pengetahuan bermakna tak terorganisasi (arbitrarily meaningful knowledge) sebagai tempat mengkaitkan pengetahuan hapalan (yang tak bermakna) untuk memudahkan retensi; (2) pengetahuan analogis (analogic knowledge) yang berada diluar isi yang sedang dibicarakan ; (3) pengetahuan tingkat yang lebih tinggi (superordinate knowledge) yang dapat berfungsi sebagai kerangka acuan bagi pengetahuan baru; (4) pengetahuan singkat (coordinate knowledge) yang dapat memenuhi fungsinya sebagai pengetahuan asosiatif dan komparatif; (5) pengetahuan tingkat yang lebih rendah (subordinate knowledge) yang berfungsi untuk mengkonkritkan pengetahuan baru atau juga penyediaan contoh-contoh; (6) pengetahuan pengalaman (experiental knowledge) yang memiliki fungsi sama dengan pengetahuan tingkat yang lebih rendah, yaitu untuk mengkonkritkan dan menyediakan contoh-contoh bagi pengetahuan baru, dan (7) strategi kognitif (cognitive strategy ) yang menyediakan cara-cara mengolah pengetahuan baru, mulai dari penyediaan, penyimpanan, sampai pada pengungkapan kembali pengetahuan yang telah tersimpan dalam ingatan

Kenyataan ini membuktikan bahwa kemampuan awal dalam belajar sangat berpengaruh terhadap peningkatan hasil belajar mahasiswa pada penguasaan materi media Pembelajaranyang diberikan. Hal ini terbukti dari hasil temuan yang menguatkan bahwa mahasiswa yang memiliki kemampuan awal belajar tinggi lebih menguasai suasana pembelajaran, lebih aktif dalam kelas, dan lebih dominan dalam sutuasi tanya jawab. Sedangkan bagi mahasiswa yang kurang kemampuan awalnya, cenderung lebih pasif, dan kelihatan ragu-ragu dalam memberikan pendapat, dan bahkan cenderung terlambat atau ketinggalan dalam memahami isi materi yang diajarkan. Berdasarkan hasil penelitian yang diperoleh memberikan gambaran bahwa dalam proses pembelajaran Media Pembelajaran sangat perlu untuk memperhatikan kemampuan awal mahasiswa dalam pembelajaran. 
Interaksi Antara Model Pembelajaran Dengan Kemampuan awal Mahasiswa Dalam Mempengaruhi Hasil Belajar Media Pembelajaran.

Dari hasil perhitungan, ditemukan bahwa tidak terdapat interaksi antara model pembelajaran dengan kemampuan awal belajar mahasiswa dalam mempengaruhi hasil belajar mahasiswa pada Media Pembelajaran. Hal ini memberikan indikasi bahwa perlakuan terhadap kelompok mahasiswa yang memiliki kemampuan awal belajar tinggi tidak perlu dibedakan dengan kelompok mahasiswa yang memiliki kemampuan awal belajar rendah. Hasil ini memberikan pengertian bahwa dalam memilih penerapan model pembelajaran yang diberikan kepada mahasiswa baik konvensional maupun dengan portofolio pada pembelajaran Media Pembelajaran tidak perlu mempertimbangkan kemampuan awal belajar mahasiswa, karena tidak akan mempengaruhi hasi belajar mahasiswa. Berdasarkan dari hasil penelitian, menunjukkan bahwa dalam pembelajaran Media Pembelajaran yang perlu dilakukan adalah menerapkan model pembelajaran portofolio dengan baik, karena model ini terbukti memberikan hasil belajar mahasiswa yang lebih baik.

Berdasarkan hasil analisis situasi pembelajaran menunjukkan bahwa tidak terjadinya interaksi pada disain penelitian ini disebabkan oleh adanya karakteristik model pembelajaran yang tidak seiring dengan perbedaan kemampuan awal mahasiswa. Seperti diketahui bahwa pada penetarapan model pembelajaran portofolio dan konvensional, dilakukan dengan tidak menindak lanjuti atau memberikan perlakuan terhadap kemampuan awal tetapi hanya berfokus terhadap proses pembelajaran yang dilakukan dalam menerapkan model dapat berjalan sebaik mungkin.

Temuan penelitian yang lebih unik menunjukkan bahwa hasil belajar mahasiswa yang memiliki kemampuan awal belajar tinggi yang diberi pembelajaran portofolio berbeda nyata dan signifikan dengan kelompok perlakuan yang lain, hal ini memberikan indikasi bahwa pembelajaran portofolio memang memberikan pengaruh yang lebih dominan dalam meningkatkan hasil belajar mahasiswa, sedangkan tiga kelompok perlakuan lainnya tidak menunjukkan perbedaan nilai kompetensi mahasiswa yang signifikan. Dengan demikian hasil penelitian ini juga memberikan gambaran bahwa rata-rata hasil belajar mahasiswa yang diberikan pembelajaran portofolio memang menunjukkan kecenderungan untuk memperoleh hasil belajar yang tinggi bagi mahasiswa yang memiliki kemampuan awal tinggi dan rendah, 
sehingga dalam meningkatkan hasil belajara mahasiswa yang terkait dengan pemilihan model penerapan pembelajaran cukup menfokuskan pada penerapan model portofolio, karena telah dibuktikan lebih unggul bila dibandingkan dengan model dengan konvensional.

\section{SIMPULAN}

Berdasarkan hasil penelitian yang diperoleh, maka dapat diambil kesimpulan bahwa kelompok mahasiswa yang memiliki aktivitas belajar tinggi memperoleh nilai hasil belajar yang lebih baik bila dibandingkan dengan kelompok mahasiswa yang memiliki aktivitas belajar rendah. Tidak terjadi interaksi antara model pembelajaran dengan aktivitas belajar mahasiswa dalam mempengaruhi hasil belajar mahasiswa pada mata kuliah Media Pembelajaran.

Model pembelajaran portofolio memberikan hasil belajar mahasiswa yang lebih baik bila dibandingkan dengan model pembelajaran konvensional pada mata kuliah Media Pembelajaran yaitu nilai rata-rata yang diperoleh mahasiswa pada kelompok yang diajar dengan model pembelajaran portofolio mencapai 22,667, sedangkan kelompok mahasiswa yang diajar dengan pembelajaran dengan konvensional hanya mencapai 18,7.

\section{DAFTAR PUSTAKA}

Ahmadi, A, dkk. Transpormasi Pendidikan Memasuki Millenium Ketiga. Yogyakarta: Kanasius. 2000

Ahmadi, A. Supriyono, w. Psikologi Belajar.Jakarta : Raja Grafindo Persada. 1995

Ariani, Ida. "Pengaruh Pembelajaran Assesmen Portofolio Terhadap Pencapaian Ketuntasan Belajar" . Tesis. Bandung. Universitas Pendidikan. 2000

Arikunto, Suharsimi. Prosedur Penelitian. Jakarta : Rineka Cipta. 1997

Ary, Jacobs, L.C., Razavieh, A. Pengantar Penelitian Pendidikan. Surabaya: Usaha Nasional. 1982

Badiran, M. "Pengembangan Model Pembelajaran Teori Seni Rupa". Jurnal Tabularasa Vol. 03 Medan: PPs Unimed. 2006

Bloom, B.S et all. Taxonomy of Education Objektives: The Clasification Of Education Goods. Handbook I : Cognitive Domain. New York : Logman Inc. 1982

Boediono, dkk. Kurikulum Berbasis Kompetensi. Jakarta: Balitbang Depdiknas. 2001 
Budimansyah, Dasim, dkk" Studi Eksperimen Pengembangan Model Pembelajaran Berbasis Portofolio di SMU Negeri 8 Bandung ”. Laporan Hasil Penelitian IKIP Bandung. 2000

Center for Indonesia Civic Education. Democratic Citizens in a Civic Society : Building Rationales for the 21 Century's Civic Education, Bandung. 1999

Dahar, Ratna Wilis. Teori- Teori Belajar. Jakarta: Erlangga. 1991

Daradjat, Zakiah. Metode Khusus Pengajaran Agama Islam. Jakarta : Bumi Aksara. 2002

Depdiknas. Kurikulum 2004 Standar Kompetensi Mata Pelajaran Matematika Sekolah Menengah Pertama. Jakarta. 2003

Dick, W and Carey, L. The systematic Design of Instructional.New York: Longman. 2005

Djahiri, Achmad Kosasih dan Soemardi. "Kami bangsa Indonesia” . Proyek Kewarganegaraan. Buku siswa, cetakan pertama, Penerjemah Sapriyah. Bandung: Centar For Indonesia Civic Education.2000

Djati Sidi, Indra. Menuju Masyarakat Belajar Menggagas, Paragdima Bagi pendidikan. Jakarta : paragdima Logos Wacana Ilmu. 2001

Edi, Sarwo. "Pengaruh Strategi Pembelajaran dengan Menggunakan Media Gambar dan Kemampuan Awal Terhadap Peningkatan Kemampuan Membaca Aman Dikelompok Bermain": Tesis. Medan Unimed. 2005

Fudyartanto, Ki, RBS. Psikologi Pendidikan dengan Pendekatan Baru. Yogyakarta : Global Pustaka Utama. 2002

Gagne, RM. The Condition of Learning and Theory of Instruction, Fourth Edition. New York : New Jersey. 1995

Hadi, Sutrisno. Bimbingan Menulis Skripsi dan Tesis. Yokyakarta: Andi Yogyakarta. 2003

Hakim, Thursan. Belajar Secara Efektif. Jakarta: Puspa Swara. 2000

Hamalik, Oemar. Kurikulum dan Pembelajaran. Jakarta: Bumi Aksara. 2003

Hidayat, M. Eddy. "Sains Teknologi Masyarakat", Makalah Disampaikan pada Seminar Literasi Sains dan Teknologi. Jakarta: Balitbang Departemen Pendidikan. 1996

Irawan, Prasetya, dkk. Teori Belajar, Motivasi, dan Keterampilan Mengajar. Departemen Pendidikan dan Kebudayaan. 1997

Joice, Bruce dan Weil, M.E. (!986). Model of Teaching. New York: Mac Millan. 
Kemp E Jerrol. Proses perancangan Pengajaran. Bandung: ITB. 1994

Miarso, Yusufhadi. Laporan Penelitian Survey Model Pengembangan Instruksional. Jakarta: PAU-PPAI Universitas Terbuka, Depdikbud. 1998

Mulyasa, Enco. Kurikulum Berbasis Kompetensi. Bandung: Remaja Rosdakarya. 2002

Nasution, Sorimuda. Metode Penelitian Naturalistik Kuantitatif. Bandung: Tarsito. 1988

Nazir, Muhammad. Metode Penelitian. Jakarta: Ghalia Indonesia.

Parji. (2002). Strategi Pembelajaran Pendidikan Moral Pada Era Teknologi Imformasi. Jakarta: PTPI dan LPTK.1981

Pidarta, Mode. Landasan Kependidikan, Stimulus Ilmu Pendidikan Bercorak Indonesia. Jakarta: Rineka Cipta. 1997

Reugeluth, C.M. Insrukctional Design Theory and Model. New Jersey: Publisher is Hilisdale. 2001

Romizwoski, A.J.Instructional Design System. Decision Making in Course Planing and CurriculumDesign. London: Kogan. 1981

Salam, Sofian. Pembelajaran Model Portofolio. Makasar: Universitas Negeri Makasar. 2000

Sanusi, Achmad. Pendidikan Alternatif. Bandung: PPS Ikip Bandung bekerja sama dengan Grafindo Medis Pratama, Bandung. 1998

Sardiman, A.M. Interaksi dan Motivasi Belajar Mengajar. Jakarta: Raja Grafindo Persada. 2003

Soekamto, Toeti. Teori Belajar dan Model- Model Pembelajaran. Jakarta: Dikti Depdikbud. 1974

Soemantri, Numan, Muhammad. Menggagas Pembaharuan Pendidikan IPS. Bandung: PT Remaja Rosdakarya. 2001

Sudjana, S. dkk. Pendidikan Kewarganegaraan. Jakarta: Gramedia Pustaka Utama. 2002

Sudjana. Metode Statistika. Bandung: Tarsito. 2002

Suryabrata, Sumadi. Psikologi Pendidikan. Jakarta: PT Raja Grafindo Persada. 1998

Usman Uzer,Moh. Menjadi Guru Profesional. Bandung: Remaja Rosdakarya. 2000

Winkel, WS. (1999). Psikologi Pengajaran. Edisi Revisi. Jakarta: Grasindo.

Yager, E Robert. STS Science/ Teknologi/Societi As Reform In Science Education.1996 